\title{
Significant Acidification in Major Chinese Croplands
}

J. H. Guo, ${ }^{1 *}$ X. J. Liu, ${ }^{1 *}$ Y. Zhang, ${ }^{1}$ J. L. Shen, ${ }^{1}$ W. X. Han, ${ }^{1}$ W. F. Zhang, ${ }^{1}$ P. Christie, ${ }^{1,2}$ K. W. T. Goulding, ${ }^{3}$ P. M. Vitousek, ${ }^{4}$ F. S. Zhang ${ }^{1} \dagger$

${ }^{1}$ College of Resources and Environmental Sciences, China Agricultural University, Beijing 100193, China. ${ }^{2}$ Agri-Environment Branch, Agri-Food and Biosciences Institute, Belfast BT9 5PX, UK. ${ }^{3}$ Department of Soil Science, Rothamsted Research, Harpenden, Herts AL5 2JQ, UK. ${ }^{4}$ Department of Biology, Stanford University, Stanford, CA 94305, USA.

*These authors contributed equally to this work.

$\dagger$ To whom correspondence should be addressed. E-mail: zhangfs@cau.edu.cn.

Soil acidification is a major problem in soils of intensive Chinese agricultural systems. We used two nationwide surveys, paired comparisons in numerous individual sites, and several long-term monitoring-field data sets to evaluate changes in soil acidity. Soil $\mathrm{pH}$ declined significantly $(P<0.001)$ from the 1980 s to the 2000 s in the major Chinese crop-production areas. Processes related to nitrogen cycling released 20 to 221 kilomoles of hydrogen ion $\left(\mathrm{H}^{+}\right)$per hectare per year, and base cations uptake contributed a further 15 to 20 kilomoles of $\mathrm{H}^{+}$per hectare per year to soil acidification in four widespread cropping systems. In comparison, acid deposition (0.4 to 2.0 kilomoles of $\mathrm{H}^{+}$per hectare per year) made a small contribution to the acidification of agricultural soils across China.

Acidification can alter the biogeochemistry of ecosystems and adversely affect biota $(1,2)$. Poorly buffered freshwater systems have been changed substantially by anthropogenic acidification (3), mostly by sulfuric and nitric acids, and the surface ocean has acidified measurably from increased carbon dioxide $\left(\mathrm{CO}_{2}\right)$ in the atmosphere, raising concerns about marine biodiversity and ecosystem function (4-6).

Anthropogenic acidification of soils has received less attention. Soils are strongly buffered by ion exchange reactions, by the weathering of soil minerals, and (in the acidic range) by interactions with aluminum (Al) and iron (7). Soils acidify very slowly under natural conditions over hundreds to millions of years. Old soils and soils in highrainfall regions tend toward greater acidity (8). Naturally acid soils occupy approximately $30 \%$ of the world's ice-free land and are commonly associated with phosphorus (P) deficiency, Al toxicity, and reduced biodiversity and productivity (9).

Chinese agriculture has intensified greatly since the early 1980s on a limited land area with large inputs of chemical fertilizers and other resources. Grain production and fertilizer nitrogen $(\mathrm{N})$ consumption reached 502 million and 32.6 million tons nationally in 2007, respectively, increases of 54 and $191 \%$ as compared with 1981 (10). High levels of N fertilization can drive soil acidification both directly and indirectly (11-13), and the rates of $\mathrm{N}$ applied in some regions are extraordinarily high (14) as compared with those of North America and Europe (15). These have degraded soils and environmental quality in the North China Plain (16) and in the Taihu Lake region in south China (14). Here, we investigate whether they also cause significant soil acidification at a national scale.

A national soil survey was conducted during the early $1980 \mathrm{~s}$, and $\mathrm{pH}$ was determined in all topsoils that were sampled (17). For comparison, we collected all published data (13) on topsoil $\mathrm{pH}$ from 2000 to 2008 and compiled two (unpaired) data sets (1980s versus 2000s) on the basis of six soil groups according to geology and use, with two subgroups per soil group: cereal crops and cash crops (tables $\mathrm{S} 1$ and $\mathrm{S} 2$ and fig. S1) (13). In China, both systems receive very high nutrient inputs as compared with those of other agricultural systems worldwide (18), especially the cash crops (such as greenhouse vegetable systems), which have developed rapidly since the 1980 s (19).

The results reveal significant acidification of all topsoils (average $\mathrm{pH}$ declines for the soil groups of 0.13 to 0.80 ) except in the highest-pH soils, which represent only a small percentage of Chinese cultivated soils (table S1). In all other soil groups, acidification has been greater in cash crop systems ( $\mathrm{pH}$ decreased by 0.30 to 0.80 ) than under cereals ( 0.13 to 0.76$)$ (Table 1$)$. These are substantial changes. The $\mathrm{pH}$ scale is logarithmic and a $\mathrm{pH}$ decrease of 0.30 corresponds to a doubling in hydrogen ion $\left(\mathrm{H}^{+}\right)$activity.

Soils in group I [for example, leached red soils (Argi-Udic Ferrosols) and yellow soils (Ali-Periudic Argosols)] are the most acidic in south China and have acidified further since the 1980 s, with $\mathrm{pH}$ declines of 0.23 and $0.30(P<0.001)$ in cereal and cash crop systems, respectively (Table 1 ). Although net $\mathrm{pH}$ decreases for group I soils were small as compared with those of other groups, the impact may be more 
pronounced because these soils are approaching $\mathrm{pH}$ values at which potentially toxic metals such as $\mathrm{Al}$ and manganese

(Mn) could be mobilized $(20,21)$.

At the other extreme, soils in group $\mathrm{V}$ [mainly fluvo-aquic soils (Ochri-Aquic Cambosols), which are widely distributed in north China] are considered resistant to acidification because of their relatively high $\mathrm{CaCO}_{3}$ content (5 to $10 \%$ ). However, they have also acidified significantly $(P<0.001)$, with $\mathrm{pH}$ decreases averaging 0.27 and 0.58 under cereals and cash crops, respectively. The $\mathrm{pH}$ decline in group $\mathrm{V}$ is small compared with those of groups III and IV (Table 1) (13) but probably resulted in substantial loss of $\mathrm{CaCO}_{3}$. Therefore, soil $\mathrm{pH}$ decline might be expected to accelerate in future.

The broad-scale comparative results are supported by data from 154 agricultural fields, in which strictly paired data were available from the same sites in the 1980s and the 2000s (13). Paired $t$ tests show that these topsoils were significantly $(P<$ 0.001 ) acidified, with an average $\mathrm{pH}$ decline of 0.50 (Fig. 1). Topsoil $\mathrm{pH}$ in $53.2 \%$ of the sites decreased by over 0.50 , $18.2 \%$ by 0.30 to 0.50 , and $18.9 \%$ by 0 to 0.30 ; only $9.7 \%$ of the sites increased in $\mathrm{pH}$. The paired national data strongly support widely occurring soil acidification in Chinese croplands.

We also summarized information from 10 long-term monitoring field (LTMF) sites in which soil $\mathrm{pH}$ was measured regularly over an 8- to 25-year period (13). Decreases in $\mathrm{pH}$ were substantial, from 0.45 to 2.20 (Fig. 2). We found significant soil acidification occurred only in NPK (conventional fertilization) plots $(P<0.001)$, whereas soil $\mathrm{pH}$ did not show obvious change in CK (no fertilization) and Fallow (no fertilization and no crop) plots (fig. S2) (13).

Further analysis shows that recent soil acidification in China has resulted mainly from high-N fertilizer inputs and the uptake and removal of base cations (BCs) by plants. In the three major Chinese double-cropping cereal systems (wheatmaize, rice-wheat, and rice-rice), annual $\mathrm{N}$ fertilizer rates are usually above $500 \mathrm{~kg} \mathrm{~N} \mathrm{ha}^{-1}$ with $\mathrm{N}$ use efficiencies of only 30 to $50 \%$ (table S3). Calculations based on inputs and outputs of ammonium and nitrate $\mathrm{N}$ indicate that $\mathrm{N}$ loading contributes 20 to $33 \mathrm{kmol} \mathrm{H}^{+} \mathrm{ha}^{-1}$ year $^{-1}$ of proton generation in these systems (Fig. 3 and table S3). Greenhouse vegetable systems, the major cash crops, receive even higher $\mathrm{N}$ fertilizer inputs; in Shandong province, $\mathrm{N}$ fertilizer rates above $4000 \mathrm{~kg} \mathrm{~N} \mathrm{ha}^{-1}$ year $^{-1}$ are common with $\mathrm{N}$ use efficiencies below $10 \%(22,23)$. Under this management, about $220 \mathrm{kmol} \mathrm{H}^{+} \mathrm{ha}^{-1}$ year $^{-1}$ of potential acidity accumulates in each hectare of soil (Fig. 3 and table S3). The proton generation related to $\mathrm{N}$ cycling (20 to $221 \mathrm{kmol} \mathrm{H}^{+}$ $\mathrm{ha}^{-1}$ year $^{-1}$ ) in China is extremely high as compared with values (1.4 to $11.5 \mathrm{kmol} \mathrm{H}^{+} \mathrm{ha}^{-1}$ year $^{-1}$ ) at lower $\mathrm{N}$ fertilizer rates in other regions (24).
Plant uptake of BCs together with removal of economic yields and crop residues from fields is another driver of soil acidification because the net removal of excess cations over anions leaves behind equivalent $\mathrm{H}^{+}$released to the soil. At current fertilization levels, approximately 25 tons of dry biomass (grain and stalk) (table S4) is harvested annually in the three double-cropping systems, leading to an estimated $\mathrm{H}^{+}$ production rate by $\mathrm{BCs}$ uptake of 15 to $20 \mathrm{kmol} \mathrm{H}^{+} \mathrm{ha}^{-1}$ year $^{-1}$ (Fig. 3 and table S3). In greenhouse vegetable systems, the importance of BCs uptake varies greatly with plant species and yield but overall appears similar to the cereal systems.

Increasing $\mathrm{N}$ fertilizer applications has been a major management technique driving high crop yields, which in turn increase the removal of BCs. These factors combined have produced potential acidity equivalent to 30 to $50 \mathrm{kmol}$ $\mathrm{H}^{+} \mathrm{ha}^{-1}$ year $^{-1}$ in double-cropping cereal systems and $\sim 230$ $\mathrm{kmol} \mathrm{H}^{+} \mathrm{ha}^{-1}$ year $^{-1}$ in greenhouse vegetable systems (Fig. 3). Although acid deposition is an important regional environmental problem in China, strongly affected areas with a precipitation $\mathrm{pH}$ of 4.00 to 5.60 (25) receive 0.4 to $2.0 \mathrm{kmol}$ $\mathrm{H}^{+}$ha $^{-1}$ year ${ }^{-1}$, much of which is buffered by other depositional or soil processes. Overall, anthropogenic acidification driven by $\mathrm{N}$ fertilization is at least 10 to 100 times greater than that associated with acid rain (13, Fig. 3 ). In other regions, serious acidification was found in the longterm $\left(\mathrm{NH}_{4}\right)_{2} \mathrm{SO}_{4}$-treated Park Grass soils at Rothamsted in England when no lime was applied to buffer soil acidity (26), and Wallace (27) reported soil acidification from routine fertilization practices for crop production.

Anthropogenic acidification of Chinese agricultural soils will be difficult to correct as long as excessive levels of $\mathrm{N}$ fertilization continue. Goulding and Annis (28) found that each $50 \mathrm{~kg} \mathrm{ha}^{-1}$ of added ammonium-N generates $\sim 4 \mathrm{kmol} \mathrm{H}^{+}$ $\mathrm{ha}^{-1}$ year $^{-1}$ and requires $\sim 500 \mathrm{~kg} \mathrm{CaCO}_{3} \mathrm{ha}^{-1}$ year $^{-1}$ to neutralize in their field conditions. Similar theoretical calculations show that each $\mathrm{kg}$ of applied $\mathrm{NH}_{4}-\mathrm{N}$ leached as $\mathrm{NO}_{3}-\mathrm{N}$ demands $7.2 \mathrm{~kg}$ of $\mathrm{CaCO}_{3}$ to neutralize the acidity generated $(29,30)$. Adding appropriate amounts of lime in China would be arduous; intensive double-cropping systems that generate 30 to $50 \mathrm{kmol} \mathrm{H}^{+} \mathrm{ha}^{-1}$ year $^{-1}$ would theoretically require 1.5 to 2.5 tons $\mathrm{CaCO}_{3}$ ha $^{-1}$ year ${ }^{-1}$ to counteract soil acidification - and greenhouse vegetable systems would require ten times this amount.

Overuse of $\mathrm{N}$ fertilizer contributes substantially to regional soil acidification in China. Since 1980, crop production has increased with rapidly increasing $\mathrm{N}$ fertilizer consumption (fig. S5). Decreasing $\mathrm{N}$ use efficiency (fig. S5) indicates that more fertilizer $\mathrm{N}$ is being lost to the environment (31), causing further negative environmental impacts. Optimal nutrient-management strategies can significantly reduce $\mathrm{N}$ fertilizer rates without decreasing crop yields $(14,32,33)$, 
with multiple benefits to agriculture and the environment (15), including the slowing of dangerous rates of anthropogenic acidification. Fertilization based on comprehensive, knowledge-based $\mathrm{N}$ management practices has become one of the most urgent requirements for sustainable agriculture in China and in other rapidly developing regions worldwide.

\section{References and Notes}

1. E. Delhaize, P. R. Ryan, Aluminum toxicity and tolerance in plants. Plant Physiol. 107, 315 (1995).

2. O. Hoegh-Guldberg et al., Coral reefs under rapid climate change and ocean acidification. Science 318, 1737 (2007).

3. P. M. Vitousek et al., Ecol. Appl. 7, 737 (1997).

4. J. C. Orr et al., Anthropogenic ocean acidification over the twenty-first century and its impact on calcifying organisms. Nature 437, 681 (2005).

5. R. A. Feely et al., Impact of anthropogenic $\mathrm{CO}_{2}$ on the $\mathrm{CaCO}_{3}$ system in the oceans. Science 305, 362 (2008).

6. J. M. Hall-Spencer et al., Volcanic carbon dioxide vents show ecosystem effects of ocean acidification. Nature $\mathbf{4 5 4}$, 96 (2008).

7. O. A. Chadwick, J. Chorover, The chemistry of pedogenic thresholds. Geoderma 100, 321 (2001).

8. H. R. von Uexküll, E. Mutert, Plant Soil 171, 1 (1995).

9. L. Blake, A. E. Johnston, K. W. T. Goulding, Mobilization of aluminium in soil by acid deposition and its uptake by grass cut for hay? A chemical time bomb. Soil Use Manage. 10, 51 (1994).

10. China Agriculture Yearbook (China Agricultural Press, Beijing, 1982-2008).

11. A. S. R. Juo, A. Dabiri, K. Franzluebbers, Acidification of a kaolinitic Alfisol under continuous cropping with nitrogen fertilization in West Africa. Plant Soil 171, 245 (1995).

12. N. Matsuyama et al., Acidification and soil productivity of allophanic Andosols affected by heavy application of fertilizers. Soil Sci. Plant Nutr. 51, 117 (2005).

13. Materials and methods are available as supporting material on Science Online.

14. X. T. Ju et al., Reducing environmental risk by improving $\mathrm{N}$ management in intensive Chinese agricultural systems. Proc. Natl. Acad. Sci. U.S.A. 106, 3041 (2009).

15. R. Howarth et al., in Ecosystems and Human Well-being: Policy Responses, K. Chopra, R. Leemans, P. Kumar, H. Simons, Eds. (Island Press, Washington, DC, 2005), pp. 295-311.

16. X. J. Liu, X. T. Ju, F. S. Zhang, J. R. Pan, P. Christie, Nitrogen dynamics and budgets in a winter wheat-maize cropping system in the North China Plain. Field Crops Res. 83, 111 (2003).

17. Soil Survey Office of China, China Soil Species, vols. 1 to 6 (China Agriculture Press, Beijing, 1994).
18. P. M. Vitousek et al., Nutrient imbalances in agricultural development. Science 324, 1519 (2009).

19. http://www.luna.com.cn/showScfx.aspx?ID=37 (2009).

20. Q. G. Zhao et al., Mechanism, Temporal-Spatial Changes and Controlling Countermeasures of Soil Degradation in Hilly Red Soil Region of Southeastern China (Science Press, Beijing, 2002), pp.202-204.

21. J. H. Guo et al., Evaluating controlling factors to $\mathrm{Al}(\mathrm{i}) /(\mathrm{Ca}+\mathrm{Mg})$ molar ratio in acidic soil water, southern and southwestern China: Multivariate approach. Environ. Monit. Assess. 129, 321 (2007).

22. J. H. Zhu, X. L. Li, P. Christie, J. L. Li, Environmental implications of low nitrogen use efficiency in excessively fertilized hot pepper ( L.) cropping systems. Agric.

Ecosyst. Environ. 111, 70 (2005).

23. X. T. Ju, C. L. Kou, P. Christie, Z. X. Dou, F. S. Zhang, Changes in the soil environment from excessive application of fertilizers and manures to two contrasting intensive cropping systems on the North China Plain. Environ. Pollut. 145, 497 (2007).

24. K. Fujii, S. Funakawa, C. Hayakawa, T. Sakartiningsih, Kosaki. Plant Soil 316, 241 (2009).

25.

www.mep.gov.cn/plan/zkgb/2008zkgb/200906/t20090609 _152566.htm (2009).

26. L. Blake, K. W. T. Goulding, C. J. B. Mott, A. E. Johnston, Changes in soil chemistry accompanying acidification over more than 100 years under woodland and grass at Rothamsted Experimental Station, UK. Eur. J. Soil Sci. 50, 401 (1999).

27. A. Wallace, Soil acidification from use of too much fertilizer. Commun. Soil Sci. Plant Anal. 25, 87 (1994).

28. K. W. T. Goulding, B. Annis, Proc. Int. Fertil. Soc. 410, 36 (1998).

29. B. Upjohn, G. Fenton, M. Conyers, http://www.dpi.nsw.gov.au/_data/assets/pdf_file/0007/16 7209/soil-acidity-liming.pdf (2005).

30. W. M. Porter, http://www.regional.org.au/au/roc/1981/roc198131.htm (1998).

31. G. X. Xing, Z. L. Zhu, Biogeochemistry 57/58, 405 (2002).

32. X. P. Chen et al., Synchronizing N supply from soil and fertilizer and $\mathrm{N}$ demand of winter wheat by an improved $\mathrm{N}_{\min }$ method. Nutr. Cycl. Agroecosyst. 74, 91 (2006).

33. G. H. Wang, Q. C. Zhang, C. Witt, R. J. Buresh, Opportunities for yield increases and environmental benefits through site-specific nutrient management in rice systems of Zhejiang province, China. Agric. Syst. 94, 801 (2007).

34. We thank X. J. Xiang for data collection, J. Wang for reference correction, and X. Shi and J. Ren for providing 
soil pH dynamics at two LTMF sites. Financial support for this work was provided by the Chinese National Basic Research Program (2009CB1 18600 and 2005CB422206), the Innovative Group Grant from NSFC (30821003), and the Special Fund for Agricultural Profession (200803030).

\section{Supporting Online Material}

www.sciencemag.org/cgi/content/full/science.1182570/DC1 Materials and Methods

SOM Text

Figs. S1 to S5

Tables S1 to S4

References and Notes

28 September 2009; accepted 14 January 2010

Published online 11 February 2010; 10.1124/science. 1182570 Include this information when citing this paper.

Fig. 1. Topsoil $\mathrm{pH}$ changes from 154 paired data over 35 sites in seven Chinese provinces between the 1980s and the 2000s.
The line and square within the box represent the median and mean values of all data; the bottom and top edges of the box represent 25 and 75 percentiles of all data, respectively; and the bottom and top bars represent 5 and 95 percentiles, respectively.

Fig. 2. Long-term changes in topsoil $\mathrm{pH}$ in some typical Chinese soils. (A) Groups I to III. (B) Groups IV and V received conventional rates of NPK fertilizers for 8 to 25 years. Soil groups are described in (13). Data are means \pm SD.

Fig. 3. $\mathrm{H}^{+}$production budget of main factors in four typical Chinese cropping systems. W-M, wheat-maize; R-W, ricewheat; R-R, rice-rice; and G-V, greenhouse vegetables. $\mathrm{N}$ cycling, $\mathrm{S}$ uptake, and $\mathrm{P}$ uptake denote the $\mathrm{H}$ produced by $\mathrm{N}$ cycling and $\mathrm{S}$ and $\mathrm{P}$ uptake processes. BCs uptake indicates $\mathrm{H}$ released by BCs uptake. Net $\mathrm{H}$ production is the algebraic sum of $\mathrm{H}$ resulting from $\mathrm{N}$ cycling and $\mathrm{P}, \mathrm{S}$, and $\mathrm{BC}$ s uptake. Data are means $\pm \mathrm{SD}$.

Table 1. Topsoil pH changes in major Chinese croplands between the 1980s and 2000s. The soil groups are defined in (13). NS, not significant; $\mathrm{pH}$ range is an average ( 5 to 95 percentile).

\begin{tabular}{|c|c|c|c|c|c|c|c|c|}
\hline \multirow{3}{*}{ Soil group } & \multicolumn{2}{|l|}{$1980 \mathrm{~s}$} & \multicolumn{6}{|l|}{$2000 \mathrm{~s}$} \\
\hline & \multirow[b]{2}{*}{ Sample number } & \multirow[b]{2}{*}{$\mathrm{pH}$ value } & \multicolumn{3}{|c|}{ Cereal crop systems* } & \multicolumn{3}{|c|}{ Cash crop systems $\dagger$} \\
\hline & & & $\begin{array}{l}\text { Sample } \\
\text { number }\end{array}$ & $\mathrm{pH}$ value & $\mathrm{pH}$ change & $\begin{array}{l}\text { Sample } \\
\text { number }\end{array}$ & $\mathrm{pH}$ value & $\mathrm{pH}$ change \\
\hline $\mathrm{I}$ & 301 & $\begin{array}{l}5.37 \\
(4.40-6.60)\end{array}$ & 505 & $\begin{array}{l}5.14 \\
(4.17-6.52)\end{array}$ & $-0.23+$ & 337 & $\begin{array}{l}5.07 \\
(3.93-6.44)\end{array}$ & $-0.30 \dagger$ \\
\hline II & 1157 & $\begin{array}{l}6.33 \\
(5.00-8.04)\end{array}$ & 1101 & $\begin{array}{l}6.20 \\
(5.00-7.70)\end{array}$ & $-0.13 \ddagger$ & 413 & $\begin{array}{l}5.98 \\
(4.58-7.49)\end{array}$ & $-0.35 \div$ \\
\hline IV & 562 & $\begin{array}{l}6.32 \\
(5.10-7.89)\end{array}$ & 537 & $\begin{array}{l}6.00 \\
(4.84-7.60)\end{array}$ & $-0.32 \ddagger$ & 238 & $\begin{array}{l}5.60 \\
(4.07-7.42)\end{array}$ & $-0.72 \ddagger$ \\
\hline $\mathrm{V}$ & 995 & $\begin{array}{l}7.96 \\
(6.39-8.80)\end{array}$ & 850 & $\begin{array}{l}7.69 \\
(5.37-8.70)\end{array}$ & $-0.27 t$ & 520 & $\begin{array}{l}7.38 \\
(5.69-8.20)\end{array}$ & $-0.58 \div$ \\
\hline VI & 493 & $\begin{array}{l}8.16 \\
(7.10-8.80)\end{array}$ & 250 & $\begin{array}{l}8.16 \\
(7.49-8.82)\end{array}$ & -0.00 (ns) & 10 & $\begin{array}{l}8.17 \\
(7.43-8.93)\end{array}$ & $0.01(\mathrm{~ns})$ \\
\hline
\end{tabular}

*Cereal/fiber crops (such as rice, wheat, maize, and cotton). $\dagger$ High-input cash crops (such as vegetables, fruit trees, and tea). $\ddagger P<0.001$. 


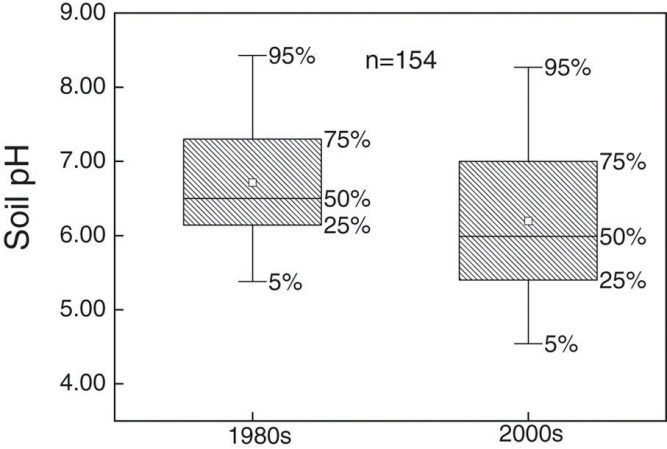




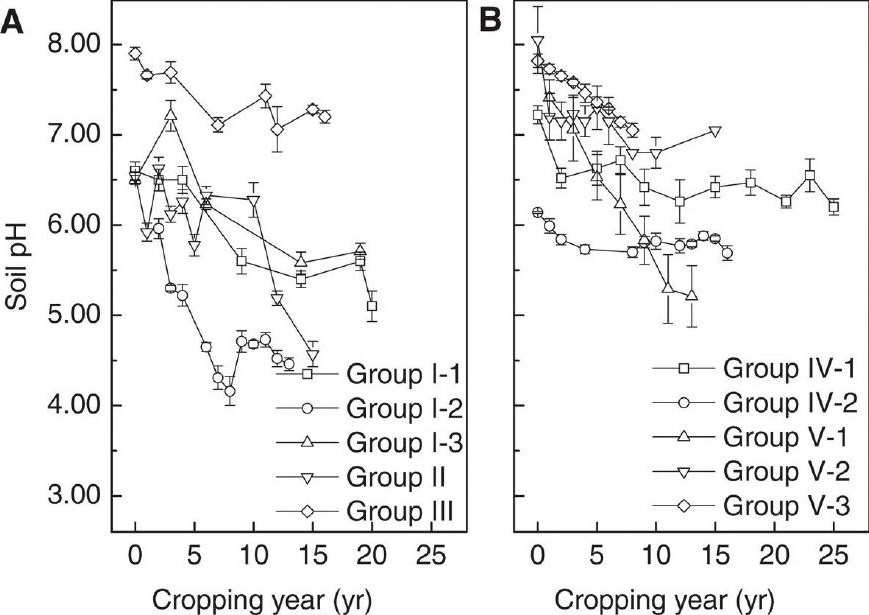




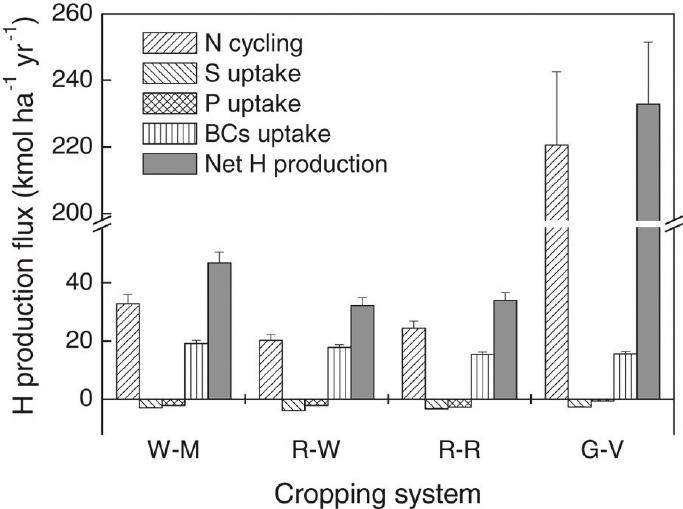

